\title{
Kombinasi Pupuk NPK dengan POC Limbah Ikan terhadap pH, P-tersedia Tanah, Serapan P, dan Hasil Baby Buncis (Phaseolus vulgaris L) pada Inceptisols asal Jatinangor
}

\author{
Nourma Al Viandari¹, Anni Yuniarti², Yuliati Machfud ${ }^{2}$ \\ 1)Kementrian Pertanian Republik Indonesia, \\ Jl. Harsono RM No.3, Ragunan, Kec. Ps. Minggu, Kota Jakarta Selatan \\ 2) Departemen Ilmu Tanah dan Sumberdaya Lahan, Fakultas Pertanian Universitas Padjadjaran \\ Jl. Raya Bandung Sumedang Km 21 Jatinangor, Sumedang
}

Korespondensi: nourmaviandari@gmail.com

\begin{abstract}
NPK compound fertilizer has the capability to improve the quality and yield of plants, but longterm application may have some effects towards soil chemical property. This study aims to find out the effect of the combination of NPK (16:16:16) and Liquid Organic Fertilizer from fish waste towards soil pH, available $P$, $P$ uptake, and yield baby bean (Phaseolus vulgaris $L$.) on Inceptisols from Jatinangor. The experiment was conducted in October 2015 until January 2016 at Experimental Farm, Faculty of Agriculture, Universitas Padjadjaran, Jatinangor, Sumedang regency, West Java. Randomized Block Design (RBD consisted of 8 treatments and repeated three times were applied in this research. The treatments were: control (0), 1 and 0,5 dose of NPK compund fertilizer, and 0,5; 1; 1,5 doses of liquid organic fertilizer from fish waste. Significant result were detected between combinations of NPK compound fertlizer and liquid organic fertilizer from fish waste on $p H$, available-P, P uptake, and yield of Baby beans (Phaseolus vulgaris L.) on Inceptisols.
\end{abstract}

Keywords: liquid organic fertilizer, fish waste, baby beans, Inceptisols

\section{PENDAHULUAN}

Kesuburan tanah mempengaruhi pertumbuhan dan produktivitas tanaman. Tanah Inceptisols menjadi ordo tanah penyebarannya cukup luas di Indonesia, bahkan di Jawa Barat ordo tanah ini tersebar dengan luasan mencapai 2,119 juta $\mathrm{Ha}$ (Subagyo dan Siswanto, 2000). Penyebaran Inceptisols yang cukup luas tersebut dapat dimanfaatkan sebagai media budidaya tanaman dengan nilai ekonomi yang prospektif di bidang pertanian. Kendalanya, Inceptisols memiliki tingkat kesuburan tanah yang cukup rendah (Abdurachman et al., 2008). Kendala tersebut dapat diatasi menggunakan teknologi tepat seperti penambahan unsur hara melalui pemupukan. Pupuk yang banyak digunakan oleh petani yaitu pupuk majemuk NPK (16:16:16). Pupuk ini memiliki kandungan hara yang seimbang (Novizan, 2007). Beberapa keunggulan lain yaitu dapat meningkatkan pertumbuhan dan hasil tanaman namun penggunaan NPK dalam jangka panjang dapat merusak tanah namun kendala tersebut dapat diatasi dengan menambahkan bahan organik ke dalam tanah.

Salah satu bahan organik yang dapat digunakan sebagai bahan pembuatan pupuk yaitu limbah ikan. Pupuk organik berbahan dasar limbah ikan memiliki kandungan unsur $\mathrm{N}$ dan P berkisar 9,63\% dan 3,26\% (Syukron, 2018). Kandungan unsur $P$ dibutuhkan tanaman terutama tanaman kacang-kacangan pada saat pembentukan polong dan biji. Penggunaan pupuk tersebut berpeluang digunakan untuk budidaya tanaman polong bernilai ekonomis tinggi seperti baby buncis.

Permintaan pasar internasional terha-dap baby buncis pada tahun 2012 berkisar 1-2 t per hari. Kelompok Tani Macakal di Desa Cibodas Lembang dapat mem-produksi baby buncis sebanyak 10-15 t pada bulan Desember 2015 hingga Februari 2016 dengan target pasar ekspor dan pasar modern. Permintaan yang 
tinggi tersebut membuat petani di berbagai daerah termasuk kelompok Tani Macakal menanam baby buncis dengan pemupukan NPK sebanyak $512 \mathrm{~kg} / \mathrm{ha}$ untuk meningkatkan produktivitas. Jumlah tersebut lebih besar jika dibandingkan dosis rekomendasi sebanyak $450 \mathrm{~kg} / \mathrm{ha}$ (Petrokimia, 2015). Jumlah yang tinggi dan penggunaan NPK dalam waktu lama dapat mempengaruhi sifat kimia tanah maka perlu dikombinasikan dengan meng-gunakan pupuk cair limbah ikan. Pupuk cair yang dianjurkan untuk tanaman bun-cis sebesar dosis $5 \mathrm{ml} \mathrm{L}^{-1}$ (Healthwealth, 2009).

Tujuan dari penelitian ini yaitu untuk mengetahui pengaruh kombinasi pupuk NPK (16:16:16) dengan POC limbah ikan terhadap pH, P-tersedia tanah, serapan P, dan hasil baby buncis (Phaseolus vulgaris L.) pada Inceptisols asal Jatinangor.

\section{METODOLOGI}

Penelitian dilaksanakan di Kebun Percobaan Ciparanje Fakultas Pertanian Universitas Padjadjaran, Jatinangor, Kabupaten Sumedang, Jawa Barat dengan ketinggian $\pm 768 \mathrm{~m}$ di atas permukaan laut. Tipe curah hujan termasuk Tipe D menurut Klasifikasi Schmidt dan Fergusson (1951) Percobaan dilaksanakan dari bulan Oktober 2015 sampai dengan Januari 2016.

Bahan yang digunakan pada percobaan ini adalah tanah Inceptisols dalam polybag berukuran $40 \mathrm{~cm}$ x $50 \mathrm{~cm}$, pupuk NPK (16:16:16), pupuk kandang yang berasal dari kotoran kambing, POC yang berbahan dasar limbah ikan, dan benih baby buncis (Phaseolus vulgaris $\mathrm{L}$.).

Alat-alat yang digunakan dalam percobaan ini adalah alat pendukung percobaan di lapangan dan alat pendukung analisis baik tanah maupun tanaman di laboratorium, seperti penggaris, kamera, alat tulis, gelas beaker, $\mathrm{pH}$ meter, dan lainnya.
Percobaan ini dilakukan dengan menggunakan Rancangan Acak Kelompok (RAK) terdiri dari 8 perlakuan dengan tiga kali pengulangan. Perlakuan diletakkan pada petak penelitian secara acak. Perlakuan yang diberikan yaitu pupuk NPK yang dikombinasikan dengan POC limbah ikan dengan berbagai dosis yaitu:

- Tanpa pupuk (kontrol),

- $512 \mathrm{~kg} / \mathrm{ha}$ NPK (16:16:16) + pupuk kandang kambing,

- $256 \mathrm{~kg} / \mathrm{ha}$ NPK $(16: 16: 16)+2,5 \mathrm{~mL} \mathrm{~L}-1$ POC limbah ikan,

- $512 \mathrm{~kg} / \mathrm{ha}$ NPK (16:16:16) + 2,5 mL L-1 POC limbah ikan,

- $256 \mathrm{~kg} / \mathrm{ha}$ NPK (16:16:16) + 5 mL L-1 POC limbah ikan,

- $512 \mathrm{~kg} / \mathrm{ha}$ NPK (16:16:16) + 5 mL L-1 POC limbah ikan,

- $256 \mathrm{~kg} / \mathrm{ha}$ NPK (16:16:16)+ 7,5 mL L-1 dosis POC limbah ikan,

- $512 \mathrm{~kg} / \mathrm{ha}(16: 16: 16)+7,5 \mathrm{~mL} \mathrm{~L}-1$ dosis POC limbah ikan

\section{HASIL DAN PEMBAHASAN}

\subsection{Analisis Tanah Awal}

Tanah yang digunakan dalam penelitian ini memiliki pH masam yaitu sebesar 6,4. Inceptisols Jatinangor memiliki tingkat ketersediaan unsur hara yang rendah seperti kandungan C-organik sebesar 1\%, N-total yaitu sebesar 0,19\%, $\mathrm{P}_{2} \mathrm{O}_{5}$ (Bray 1) sebesar $8.06 \mathrm{mg}$ $\mathrm{kg}^{-1}, \mathrm{~K}_{2} \mathrm{O}$ ( $\mathrm{HCl} 25 \%$ ) sebesar 8,25 mg $100 \mathrm{~g}^{-1}$. Kandungan liat pada Inceptisols yang digunakan pada percobaan ini yaitu 57\%. Tanah dengan tekstur liat memiliki luas permukaan yang besar karena ukuranya lebih halus sehingga mampu menahan air (Hardjowigeno, 2010).

Hasil analisis tanah awal menunjukkan kadar kation Ca dan Mg sebesar 5,44 cmol kg-1 dan 2,60 $\mathrm{cmol} \mathrm{kg}^{-1}$. Kapasitas tukar kation (KTK) sebesar 17,40 $\mathrm{cmol} \mathrm{kg}^{-1}$ dengan kriteria sedang dan kejenuhan basa yang tergolong 
sedang yaitu sebesar 48,91\%. Berdasarkan analisis tersebut dapat diketahui bahwa tingkat efisiensi pemupukan menjadi rendah. Hal tersebut dikarenakan kation tanah mudah tercuci sehingga tidak optimal diserap tanaman (Tuherkih dan Sipahutar, 2009).

Kriteria unsur hara N, P dan K yang rendah dan $\mathrm{pH}$ tanah yang agak masam menunjukkan bahwa tanah ini memerlukan pasokan unsur hara yang tepat terutama untuk tanaman baby buncis sehingga baby buncis dapat tumbuh optimal.

\subsection{Analisis POC Limbah Ikan}

Hasil analisis POC limbah ikan menunjukkan bahwa POC limbah ikan yang diuji mempunyai $\mathrm{pH}$ 8,8. Analisis POC limbah ikan juga menunjukkan hasil C-organik sebesar 7\%, $\mathrm{N}$-total $0,16 \%$, Kadar $\mathrm{P}_{2} \mathrm{O}_{5}$ dan $\mathrm{K}_{2} \mathrm{O}$ masingmasing $0,02 \%$ dan 0,47\%. Kandungan N, P, dan $\mathrm{K}$ tersebut belum memenuhi persyaratan Pupuk Organik Cair yang ditetapkan oleh Kementerian Pertanian Tahun 2011. Kandungan yang rendah diduga akibat kurangnya dosis tepung ikan yang diberikan.
Menurut Syukron (2018), kandungan unsur hara $P$ berbanding lurus dengan proporsi tepung ikan yang ditambahkan. Selain itu, Kandungan unsur $\mathrm{P}$ juga mempunyai korelasi dengan kandungan unsur N. Menurut Hidayati et al., (2008), Besarnya kandungan unsur $\mathrm{N}$ pada suatu pupuk mempengaruhi aktivitas mikro-organisme dalam merombak $P$. Komposisi bahan baku dan penggunaan teknologi yang tepat dapat menghasilkan pupuk berkualitas (Suwahyono, 2011).

\subsection{Pertumbuhan Tanaman}

Pengamatan pertumbuhan baby buncis berdasarkan tinggi tanaman. Pengamatan dilakukan dengan interval waktu satu minggu sekali. Pengamatan dimulai saat tanaman memasuki umur 2 MST hingga 4 MST. Tinggi tanaman menjadi salah satu parameter yang diamati baik sebagai indikator pertumbuhan maupun sebagai parameter untuk mengukur pengaruh lingkungan maupun perlakuan yang diberikan. Hasil pengamatan pertumbuhan tanaman pada masing-masing perlakuan disajikan pada Gambar 1.

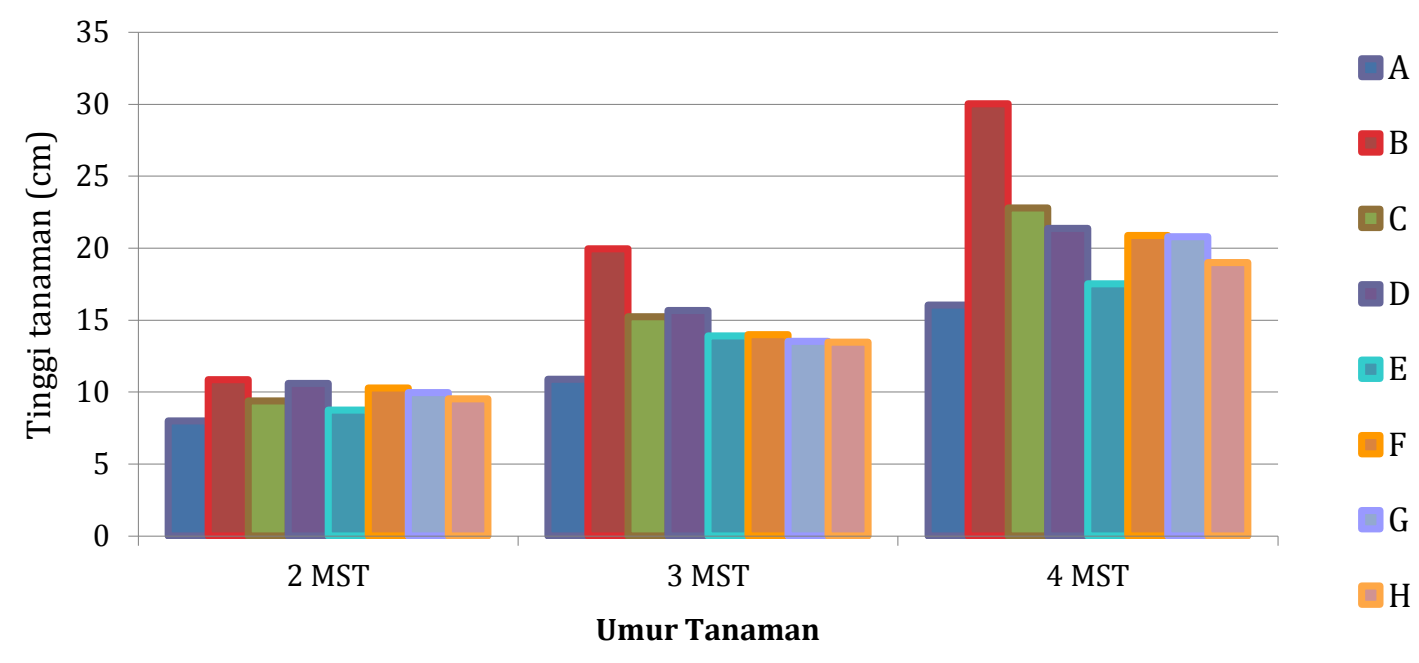

Gambar 1 Histogram Pertumbuhan Tinggi Tanaman (cm) yang Dipengaruhi oleh Kombinasi Pupuk NPK Majemuk dengan POC limbah ikan

Pertumbuhan tanaman tertinggi pada perlakuan $512 \mathrm{~kg} / \mathrm{ha} \mathrm{NPK}+$ pupuk kandang kambing yaitu sebesar $10,86 \mathrm{~cm}$ pada $2 \mathrm{MST}$, 19,94 pada 3 MST, dan 30,04 pada 4 MST. Hal 
ini diduga aplikasi pupuk kandang kambing pada tanah dapat memperbaiki struktur tanah sehingga secara tidak langsung menaikkan jumlah unsur hara dalam tanah dan berpengaruh terhadap pertumbuhan tanaman. Menurut Rihana et al. (2013), pupuk kandang kambing berpengaruh terhadap pertumbuhan dan hasil tanaman buncis.

Pupuk kandang dapat memperbaiki struktur tanah karena mengandung unsur hara dan mineral. Pupuk kandang kambing juga mudah terdekomposisi membuat struktur tanah menjadi gembur, memudahkan akar menembus tanah dan menyerap ion hara. Menurut Parnata (2010), proses dekomposisi pupuk kambing berpengaruh terhadap pertumbuhan tanaman dikarenakan akar lebih optimum dalam menyerap ion hara. Apabila media tanam memiliki kandungan hara yang optimum maka asimilat yang dihasilkan juga akan lebih maksimum (Afif et al., 2014).

Pertumbuhan tanaman baby buncis terendah pada Gambar 1 didapat pada perlakuan kontrol atau tanpa pemberian pupuk yaitu $8 \mathrm{~cm}$ pada minggu pertama, $12,2 \mathrm{~cm}$ pada minggu kedua dan $17.46 \mathrm{~cm}$ pada minggu ketiga. Perlakuan tanpa pemberian pupuk mengakibatkan kurangnya ketersediaan unsur hara yang dibutuhkan oleh tanaman baby buncis yang berakibat pada pertumbuhan yang kurang optimal.

\subsection{Kemasama Tanah}

Kemasaman Tanah $(\mathrm{pH})$ berpengaruh terhadap tingkat kesuburan tanah yang nantinya berpengaruh terhadap keter-sediaan unsur hara dan pertumbuhan tanaman (Fageria et al., 1991). Aktivitas mikroorganisme dalam tanah juga berpengaruh terhadap peningkatan $\mathrm{pH}$. Menurut White (2006) ekskresi mikroorganisme dapat berpengaruh terhadap reaksi basa di dalam tanah. Hasil analisis $\mathrm{pH}$ tanah disajikan pada Tabel 1.
Tabel 1 Pengaruh Kombinasi Pupuk NPK dengan POC Limbah Ikan terhadap pH Tanah

\begin{tabular}{|c|c|}
\hline Perlakuan & $\mathrm{pH}$ \\
\hline $\mathrm{A}=$ Tanpa pupuk (kontrol) & $6,5 \mathrm{~b}$ \\
\hline $\begin{array}{l}\mathrm{B}=512 \mathrm{~kg} / \mathrm{ha} \text { NPK + pupuk } \\
\text { kandang kambing }\end{array}$ & $6,2 \mathrm{ab}$ \\
\hline $\begin{array}{l}\mathrm{C}=256 \mathrm{~kg} / \mathrm{ha} \mathrm{NPK}+2,5 \mathrm{~mL} \mathrm{~L}^{-1} \mathrm{POC} \\
\text { Limbah Ikan }\end{array}$ & 5,9 a \\
\hline $\begin{array}{l}\mathrm{D}=512 \mathrm{~kg} / \mathrm{ha} \mathrm{NPK}+2,5 \mathrm{~mL} \mathrm{~L}^{-1} \mathrm{POC} \\
\text { Limbah Ikan }\end{array}$ & 5,9 a \\
\hline $\begin{array}{l}\mathrm{E}=256 \mathrm{~kg} / \mathrm{ha} \mathrm{NPK}+5 \mathrm{~mL} \mathrm{~L}^{-1} \mathrm{POC} \\
\text { Limbah Ikan }\end{array}$ & $6,0 \mathrm{a}$ \\
\hline $\begin{array}{l}\mathrm{F}=512 \mathrm{~kg} / \mathrm{ha} \mathrm{NPK}+5 \mathrm{~mL} \mathrm{~L}^{-1} \mathrm{POC} \\
\text { Limbah Ikan }\end{array}$ & $6,0 \mathrm{a}$ \\
\hline $\begin{array}{l}\mathrm{G}=256 \mathrm{~kg} / \mathrm{ha} \mathrm{NPK}+7,5 \mathrm{~mL} \mathrm{~L}^{-1} \mathrm{POC} \\
\text { Limbah Ikan }\end{array}$ & $6,4 \mathrm{~b}$ \\
\hline $\begin{array}{l}\mathrm{H}=512 \mathrm{~kg} / \mathrm{ha} \mathrm{NPK}+7,5 \mathrm{~mL} \mathrm{~L}^{-1} \mathrm{POC} \\
\text { Limbah Ikan }\end{array}$ & $6,1 \mathrm{ab}$ \\
\hline
\end{tabular}

Perlakuan pupuk NPK majemuk yang dikombinasikan dengan POC limbah ikan dapat menaikkan dan menurunkan pH. Tabel 1 menjelaskan bahwa pada perla-kuan 256 $\mathrm{kg} / \mathrm{ha} \mathrm{NPK}+7,5 \mathrm{~mL} \mathrm{~L}^{-1}$ POC Limbah Ikan tidak terjadi peningkatan $\mathrm{pH}$ dari analisis tanah awal percobaan yaitu sebesar 6,4. Perlakuan 256 $\mathrm{kg} / \mathrm{ha} \mathrm{NPK}+7,5 \mathrm{~mL} \mathrm{~L}^{-1}$ POC Limbah Ikan memiliki $\mathrm{pH}$ yang berbeda nyata terhadap perlakuan $256 \mathrm{~kg} / \mathrm{ha} \mathrm{NPK}+2,5 \mathrm{~mL} \mathrm{~L}^{-1} \mathrm{POC}$, = $256 \mathrm{~kg} / \mathrm{ha} \mathrm{NPK}+5 \mathrm{~mL} \mathrm{~L}^{-1}$ POC Limbah Ikan, = $512 \mathrm{~kg} / \mathrm{ha}$ NPK $+5 \mathrm{~mL} \mathrm{~L}^{-1}$ POC Limbah Ikan namun tidak berbeda nyata dengan perlakuan kontrol, $512 \mathrm{~kg} / \mathrm{ha}$ NPK + pupuk kandang kambing dan $512 \mathrm{~kg} / \mathrm{ha} \mathrm{NPK}+7,5 \mathrm{~mL} \mathrm{~L}^{-1} \mathrm{POC}$ Limbah Ikan.

Pada Tabel 1 mendeskripsikan adanya penurunan $\mathrm{pH}$ pada perlakuan $512 \mathrm{~kg} / \mathrm{ha} \mathrm{NPK}$ + pupuk kandang kambing, $256 \mathrm{~kg} / \mathrm{ha} \mathrm{NPK}+$ 2,5 mL L-1 POC Limbah Ikan, $512 \mathrm{~kg} / \mathrm{ha}$ NPK + 2,5 mL L-1 POC Limbah Ikan, $256 \mathrm{~kg} / \mathrm{ha}$ NPK + $5 \mathrm{~mL} \mathrm{~L}-1$ POC Limbah Ikan, $512 \mathrm{~kg} / \mathrm{ha}$ NPK + 5 mL L-1 POC Limbah Ikan dan $512 \mathrm{~kg} / \mathrm{ha}$ NPK + 7,5 mL L-1 POC Limbah Ikan apabila 
dibandingkan dengan hasil analisis $\mathrm{pH}$ tanah pada awal percobaan.

Penurunan $\mathrm{pH}$ diduga akibat adanya beberapa faktor di antaranya kurangnya dosis POC limbah ikan yang diaplikasikan sehingga tidak meningkatkan $\mathrm{pH}$ tanah, selain itu adanya aplikasi pupuk NPK yang dapat mengembangkan sisa asam dalam tanah. White (2006) menyebutkan bahwa pupuk NPK majemuk cenderung mengem-bangkan sisa asam dalam tanah. Hal ini terutama disebabkan oleh pengaruh unsur $\mathrm{N}$ pada NPK yang mengandung amonia. Ion $\mathrm{NH}_{4}$ berpengaruh apabila ion ini mengalami nitrifikasi.

Perlakuan kontrol memiliki pH yang lebih tinggi sebesar 6.5 jika dibandingkan dengan $\mathrm{pH}$ pada analisis tanah awal. Kenaikan pH ini diduga akibat beberapa faktor di antaranya pemeliharaan tanaman seperti penyiraman dan aktivitas organisme dalam tanah. Menurut Buckman dan Brady (1982), adanya penyiraman dapat mem-pengaruhi $\mathrm{pH}$ dikarenakan air dapat mengandung berbagai macam garam yang kationnya dapat diadsorpsi oleh koloida tanah sehingga meningkatkan $\mathrm{pH}$ tanah.

\subsection{P- Tersedia}

Pada Tabel 2 dapat diketahui bahwa masing-masing perlakuan memberikan pengaruh terhadap P-Tersedia pada Inceptisols Jatinangor. Kandungan P-tersedia pada kontrol mengalami kenaikan dari ana-lisis Ptersedia tanah pada awal percobaan yaitu sebesar $8,06 \mathrm{mg} / \mathrm{kg}$ menjadi $16,7 \mathrm{mg} / \mathrm{kg}$. Ketersediaan $\mathrm{P}$ dapat meningkat di-duga akibat adanya pengaruh $\mathrm{pH}$ tanah. Black (1964) mengemukakan bahwa keter-sediaan $P$ meningkat dengan seiring meningkatnya $\mathrm{pH}$ tanah.

Eksudat akar juga mempengaruhi ketersediaan $\mathrm{P}$ dikarenakan tanaman dan mikroba saling berinteraksi dikarenakan eksudat akar (Schroder dan Hartmann 2003).
Eksudat akar mempengaruhi aktivitas dan populasi mikroorganisme di rizosfer, rizoplan, dan sekitarnya (Schottendreier dan Falkengren-Greup, 1999). Mikroorganisme di sekitar perakaran membantu pelarutan $\mathrm{P}$ yang umumnya tidak terlarut sehingga dapat tersedia bagi tanaman (Gaur et al., 1980).

Tabel 2 Pengaruh Kombinasi Pupuk NPK dengan POC Limbah Ikan terhadap pH Tanah

\begin{tabular}{|c|c|}
\hline Perlakuan & $\begin{array}{l}\text { P-Tersedia } \\
\left(\mathrm{mg} \mathrm{kg}^{-1}\right)\end{array}$ \\
\hline $\mathrm{A}=$ Tanpa pupuk (kontrol) & $16,73 \mathrm{a}$ \\
\hline $\begin{array}{l}\mathrm{B}=512 \mathrm{~kg} / \mathrm{ha} \mathrm{NPK}+\text { pupuk kandang } \\
\text { kambing }\end{array}$ & $45,77 \mathrm{~b}$ \\
\hline $\begin{array}{l}\mathrm{C}=256 \mathrm{~kg} / \mathrm{ha} \mathrm{NPK}+2,5 \mathrm{~mL} \mathrm{~L}^{-1} \mathrm{POC} \\
\text { Limbah Ikan }\end{array}$ & $46,30 \mathrm{~b}$ \\
\hline $\begin{array}{l}\mathrm{D}=512 \mathrm{~kg} / \mathrm{ha} \mathrm{NPK}+2,5 \mathrm{~mL} \mathrm{~L}^{-1} \mathrm{POC} \\
\text { Limbah Ikan }\end{array}$ & $31,07 \mathrm{ab}$ \\
\hline $\begin{array}{l}\mathrm{E}=256 \mathrm{~kg} / \mathrm{ha} \mathrm{NPK}+5 \mathrm{~mL} \mathrm{~L}^{-1} \mathrm{POC} \\
\text { Limbah Ikan }\end{array}$ & $38,93 \mathrm{~b}$ \\
\hline $\begin{array}{l}\mathrm{F}=512 \mathrm{~kg} / \mathrm{ha} \mathrm{NPK}+5 \mathrm{~mL} \mathrm{~L}-1 \mathrm{POC} \\
\text { Limbah Ikan }\end{array}$ & $33,27 \mathrm{ab}$ \\
\hline $\begin{array}{l}\mathrm{G}=256 \mathrm{~kg} / \mathrm{ha} \mathrm{NPK}+7,5 \mathrm{~mL} \mathrm{~L}^{-1} \mathrm{POC} \\
\text { Limbah Ikan }\end{array}$ & $53,90 \mathrm{~b}$ \\
\hline $\begin{array}{l}\mathrm{H}=512 \mathrm{~kg} / \text { ha } \mathrm{NPK}+7,5 \mathrm{~mL} \mathrm{~L}^{-1} \mathrm{POC} \\
\text { Limbah Ikan }\end{array}$ & $43,80 \mathrm{~b}$ \\
\hline $\begin{array}{r}\text { Keterangan : Angka-angka yang berhuruf } \\
\text { berbeda nyata menurut } \\
\text { Berganda Duncan pada taraf }\end{array}$ & $\begin{array}{ll}\text { sama tidak } \\
\text { Uji } & \text { Jarak } \\
5 \% & \end{array}$ \\
\hline
\end{tabular}

Pada Tabel 2, perlakuan $256 \mathrm{~kg} / \mathrm{ha}$ NPK + 7,5 mL L-1 POC Limbah Ikan memiliki nilai Ptersedia tertinggi dan berpengaruh nyata terhadap kontrol namun tidak berpengaruh nyata terhadap perlakuan kombinasi NPK dan POC lainnya. Kandungan P-tersedia yang tinggi pada perlakuan $256 \mathrm{~kg} / \mathrm{ha} \mathrm{NPK}+7,5 \mathrm{~mL} \mathrm{~L}-1$ POC Limbah Ikan diduga akibat adanya kombinasi yang sesuai antara dosis pupuk NPK majemuk dengan dosis POC limbah ikan yang diberikan. Hal tersebut dikarenakan pupuk NPK memiliki sumbangsih unsur $P$ dalam tanah. Menurut Jones (1982), pemanfaatan $P$ oleh tanaman hanya sebesar 10-30\% dari pupuk NPK yang diaplikasikan sehingga terdapat 70 hingga $90 \%$ pupuk $\mathrm{P}$ yang tetap berada dalam tanah. Sebagian besar bahkan 
hampir 90\% unsur P yang diberikan melalui pemupukan tidak terserap oleh tanaman namun tertahan menjadi bentuk terfiksasi oleh unsur lain seperti $\mathrm{Al}, \mathrm{Fe}$, dan Mn berakibat pada tidak larut dan tidak tersedia bagi tanaman.

Penambahan POC limbah ikan mampu menaikkan nilai P-tersedia tanah diduga adanya bahan organik yang terkandung pada POC limbah ikan. Menurut Tan (1991), bahan organik selain berfungsi sebagai sumber hara makro dan mikro untuk tanaman juga mempunyai kaisan erat dengan populasi dan aktivitas mikro-organisme tanah yang mampu melarutkan P sehingga tersedia bagi tanaman.

Dekomposisi bahan organik menghasilkan asam-asam organik yang memiliki kemampuan mengikat kation melalui ikatan kelasi dan mampu menyelimuti koloida bermuatan positif dan mampu mendesak $\mathrm{P}$ yang telah berada pada kompleks jerapan tanah (LopezHernandez et al., 1979) sehingga residu P yang berasal dari pupuk majemuk NPK dapat menjadi tersedia akibat proses fiksasi $\mathrm{P}$ oleh bahan organik yang terkandung dalam POC.

\subsection{Serapan $P$}

Hasil pengukuran dan analisis ragam serapan $\mathrm{P}$ dapat dilihat pada Tabel 3. Nilai serapan $\mathrm{P}$ tertinggi sebesar $1,44 \mathrm{mg} /$ tanaman terdapat pada perlakuan $512 \mathrm{~kg} / \mathrm{ha} \mathrm{NPK}+$ pupuk kandang kambing. Hasil tertinggi tersebut diduga akibat adanya penambahan pupuk kandang kambing sebagai pupuk organik yang ditambahkan. Pupuk kandang kambing dapat berpengaruh terhadap kemampuan akar dalam menembus tanah. Kemampuan akar dalam menembus tanah berakibat pada banyaknya ion yang diserap oleh akar termasuk unsur P (Parnata, 2010).

Dekomposisi bahan organik dari pupuk kandang kambing dapat mempengaruhi ketersediaan unsur $\mathrm{N}$ dan $\mathrm{P}$ sehingga memungkinkan untuk diserap tanaman. Stevenson (1999) mengemukakan bahwa serapan $\mathrm{P}$ dapat meningkat dengan pengaruh eksudat akar yang dihasilkan oleh mikroorganisme tanah yang terdapat pada pupuk kandang kambing.

Tabel 3 Pengaruh Kombinasi Pupuk NPK dengan POC Limbah Ikan terhadap serapan $\mathrm{P}$

\begin{tabular}{lc}
\hline \multicolumn{1}{c}{ Perlakuan } & $\begin{array}{c}\text { Serapan P } \\
\text { (mg/tanaman) }\end{array}$ \\
\hline A = Tanpa pupuk (kontrol) & $0,37 \mathrm{a}$ \\
B = 512 kg/ha NPK + pupuk & $1,44 \mathrm{~b}$ \\
kandang kambing & \\
C = 256 kg/ha NPK + 2,5 mL L-1 & $0,86 \mathrm{ab}$ \\
POC Limbah Ikan & \\
D = 512 kg/ha NPK + 2,5 mL L-1 & $0,47 \mathrm{a}$ \\
POC Limbah Ikan & \\
E = 256 kg/ha NPK + 5 mL L-1 & $0,80 \mathrm{a}$ \\
POC Limbah Ikan & \\
F = 512 kg/ha NPK + 5 mL L-1 & $0,49 \mathrm{a}$ \\
POC Limbah Ikan & \\
G = 256 kg/ha NPK + 7,5 mL L-1 & $0,64 \mathrm{a}$ \\
POC Limbah Ikan & \\
H = 512 kg/ha NPK + 7,5 mL L-1 & $0,64 \mathrm{a}$ \\
POC Limbah Ikan & \\
\hline
\end{tabular}

Keterangan : Angka-angka yang berhuruf sama tidak berbeda nyata menurut Uji Jarak Berganda Duncan pada taraf 5\%

Eksudat akar yang dihasilkan dalam bentuk asam organik sehingga mening-katkan jumlah P-tersedia untuk tanaman. Pertukaran kation dan anion oleh bantuan mikoriza juga dapat meningkatkan $\mathrm{pH}$ dengan demikian dapat mengubah jumlah $\mathrm{P}$ yang diserap oleh tanaman.

Kombinasi pupuk NPK dengan POC limbah ikan memberikan hasil yang lebih rendah dibanding dengan perlakuan $\mathrm{B}$ diduga akibat dari pengaruh kemampuan tanaman dalam menyerap $\mathrm{P}$ bergantung pada lingkungan. Menurut Effendy (2008) konsentrasi P yang pekat dapat meng-ganggu sistem perakaran sehingga ber-pengaruh terhadap kemampuan akar dalam menyerap unsur P. Metode pemberian POC limbah ikan pada tanah juga dapat berpengaruh terhadap serapan P. 


\subsection{Hasil Baby Buncis}

Komponen hasil yang dianalisis adalah bobot hasil (segar) dari masing-masing tanaman. Hasil pengukuran dan analisis ragam terhadap bobot baby buncis dapat dilihat pada Tabel 4. Perlakuan $512 \mathrm{~kg} / \mathrm{ha}$ NPK + pupuk kandang kambing memiliki bobot hasil yang lebih tinggi yaitu sebesar 92,25 g. Perlakuan pupuk NPK dan pupuk kandang memiliki hasil yang tinggi diduga akibat adanya kandungan unsur hara yang berpengaruh terhadap pertumbuhan polong tanaman. Hartatik dan Widowati (2006) menyatakan bahwa pupuk kandang kam-bing memiliki kandungan hara $\mathrm{P}$ dan K yang relatif lebih tinggi dibanding pupuk kandang lainnya.

Tabel 4 Pengaruh Kombinasi Pupuk NPK dengan POC Limbah Ikan terhadap Hasil

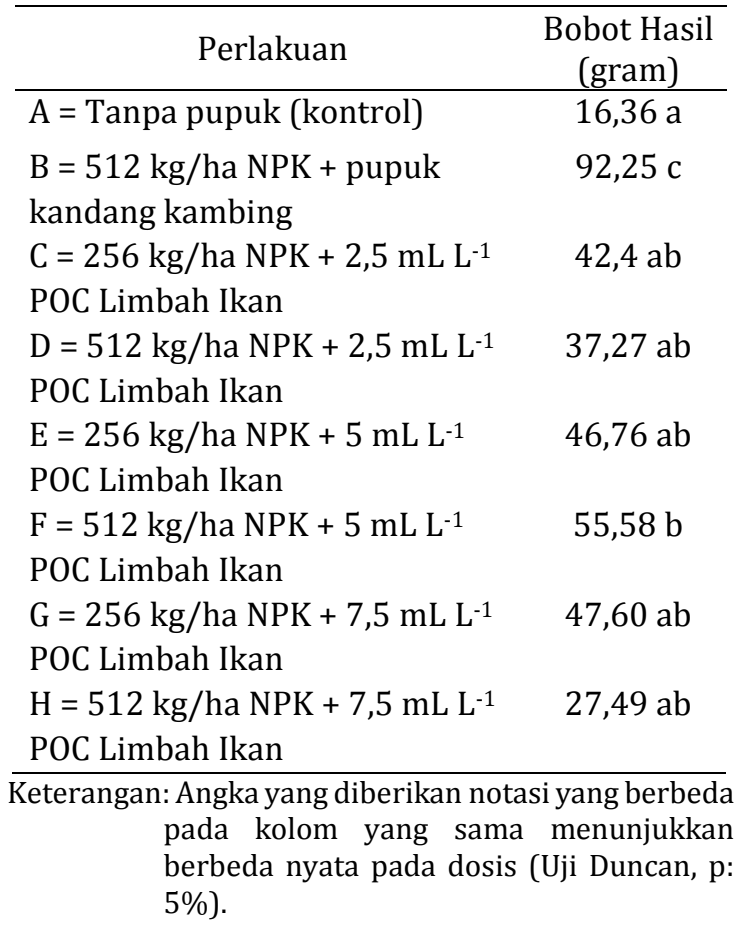

Kombinasi pupuk NPK dan POC limbah ikan belum memberikan hasil tertinggi baby buncis jika dibandingkan dengan perlakuan $512 \mathrm{~kg} / \mathrm{ha}$ NPK + pupuk kandang kambing. Kombinasi pupuk NPK dan POC limbah ikan yang dapat memberikan hasil tertinggi setelah perlakuan $512 \mathrm{~kg} / \mathrm{ha} \mathrm{NPK}+$ pupuk kandang kambing adalah perlakuan $256 \mathrm{~kg} / \mathrm{ha}$ NPK +
7,5 mL L-1 POC Limbah Ikan diduga dosis tersebut merupakan kombinasi antara dosis NPK dengan dosis POC limbah ikan yang optimum untuk mendapatkan hasil yang tinggi pada baby buncis.

Hasil yang rendah pada perlakuan kombinasi NPK dengan POC limbah ikan jika dibandingkan dengan perlakuan $\mathrm{B}$ diduga akibat pengaruh interval waktu pemberian dan takaran dosis yang dibe-rikan. Berdasarkan Dwijoseputro (2000), tanaman dapat tumbuh optimal jika unsur hara yang berada di dalam tanah cukup tersedia dan dapat diserap oleh tanaman. Gardner et al. (1991) juga berpendapat bahwa terdapat beberapa faktor yang mempengaruhi pertumbuhan dan hasil yaitu kondisi dan lingkungan. Di antaranya unsur hara yang tersedia serta adanya pengendalian hama dan penyakit tanaman.

Pertumbuhan dan hasil dapat meningkat dengan memperhatikan dosis dan rentan waktu pemberian pupuk yang tepat. Kelik (2010) menyatakan bahwa Ketepatan dalam pemberian pupuk dapat memberikan hasil yang optimal pada pertumbuhan dan hasil tanaman selain itu juga perlu memperhatikan faktor pendukung lain seperti cahaya dan air untuk membantu proses fotosintesis. Menurut Hanolo (1997), perlu memperhatikan konsentrasi dalam pemberian pupuk organik ke dalam tanah. Lingga dan Marsono (2013) mengemukakan bahwa keberhasilan pemupukan dipengaruhi oleh konsentrasi yang tepat dalam pemberian pupuk.

Faktor lain yang mengakibatkan hasil panen rendah pada perlakuan kombinasi pupuk NPK dengan POC limbah ikan yaitu suplai unsur hara dari POC limbah ikan belum mampu memberikan sumbangsih yang besar jika dibandingkan dengan pupuk kandang kambing sehingga penggunaan pupuk kandang kambing tetap harus diberikan sebagai pupuk dasar untuk mendapatkan hasil baby buncis yang optimum. 


\section{KESIMPULAN}

Kombinasi pupuk NPK (16:16:16) dan POC limbah ikan berpengaruh Terdapat pengaruh pada karakteristik tanah pada Inceptisols Jatinangor yaitu $\mathrm{pH}, \mathrm{P}$-tersedia, serapan $\mathrm{P}$ tanaman baby buncis. Selain itu Kombinasi pupuk NPK (16:16:16) dan POC limbah ikan berpengaruh kepada hasil baby buncis (Phaseolus vulgaris $\mathrm{L}$ ).

\section{DAFTARPUSTAKA}

Abdurachman A, A. Dariah, dan A. Mulyani. 2008. Strategi dan teknologi pengelolaan lahan kering mendukung pengadaan pangan nasional. J. Litbang Pertanian 27(2): 43-49.

Afif, T., D. Kastono, P. Yudono. 2014. Pengaruh macam pupuk kandang terhadap pertumbuhan dan hasil tiga kultivar kacang hijau (Vigna radiata L. Wilczek) di lahan pasir pantai Bugel, Kulon Progo. Vegetalika, 3(3): 78 - 88.

Black, C. A. 1964. Soil-Plant Relationships. John Wiley \& Sons, Inc. United States of America.

Buckman, H. O. dan Brady. 1982. Ilmu Tanah. Terjemahan Soegiman. Bharat Karya Aksara, Jakarta.

Dwijoseputro, D. 2000. Pengantar Fisiologi Tumbuhan. Gramedia, Jakarta.

Gardner, F. P., R. B. Pearce and R. L. Mitchell. 1991. Physiology of Crop Plants (Fisiologi Tanaman Budidaya, alih bahasa oleh Susilo). UI Press. Jakarta.

Gaur, A.C., R.S. Mathur, and K.V. Sadasivam. 1980. Effect of Organic Material and Phosphate-dissolving Culture on The Yield of Wheat and Greengram. Indian J. Agron. 25: 501-503

Hanolo, W. 1997. Tanggapan Tanaman Selada dan Sawit Terhadap Dosis dan Cara Pemberian Pupuk Cair. Stimulan Jurnal Agrotropika 1(1): 25-29.
Hardjowigeno, S. 2010. Ilmu Tanah. Akademika Pressindo, Jakarta.

Hartatik, W dan L.R. Widowati. 2006. Pupuk kandang. Dalam Simanungkalit dkk (Eds.). Pupuk Organik dan Pupuk Hayati. Balai Besar Litbang Sumberdaya Lahan Pertanian, Bogor.

Healthwealth. 2009. Panduan Penggunaan Top G2. Diakses melalui http://www.healthwealthint.com/deta il.asp? pada 21 September 2015

Jones, U. S. 1982. Fertilizer and Soil Fertility. Reston Publishing Company, Reston, Virginia.

Kelik, W. 2010. Pengaruh kosentrasi dan Frekuensi Pemberian Pupuk Organik cair hasil perombakan Anaerob Limbah Makanan Terhadap Pertumbuhan Tanaman Sawi (Brassica juncea L.). Jurnal Agrosains 19(4): 11 134.

Kementerian Pertanian. 2011. Peraturan Menteri Pertanian tentang Pupuk Organik, Pupuk Hayati dan Pembenah Tanah.

Lingga, P dan Marsono. 2013. Petunjuk Penggunaan Pupuk. Penebar Swadaya, Jakarta.

Novizan. 2007. Petunjuk Pemupukan Yang Efektif. Agromedia Pustaka. Jakarta.

Parnata, A. S. 2010. Meningkatkan Hasil Panen Dengan Pupuk Organik. Agromedia Pustaka. Jakarta.

Petrokimia. 2015. Anjuran Umum Pemupukan Berimbang Menggunakan Pupuk. Diakses melalui website resmi Petrokimia Gresik: www.petrokimiagresik.com pada 10 September 2015.

Rihana, S., Y. B. Suwassono Heddy, M. Dawam Maghfoer. 2013. Pertumbuhan dan hasil tanaman buncis (Phaseolus vulgaris L.) pada berbagai dosis pupuk kotoran kambing dan konsentrasi zat pengatur tumbuh dekamon. Jurnal Produksi Tanaman 1(4): 369 - 377. 
Schottendreier, M. and U. Falkengren-Greup. 1999. Plant Induced Alteration in the Rhizosphere and The Utilization of Soil Heterogenicity. Plant Soil 209: 297309.

Stevenson, F.J. 1999. Cycles of Soil. John Wiley \& Sons, Inc. United States.

Subagyo, H., N. Suharta, dan A.B. Siswanto. 2000. Tanah-tanah pertanian di Indonesia. Dalam Pusat Penelitian Tanah dan Agroklimat (Ed.). Sumberdaya lahan Indonesia dan Pengelolaannya. Pusat Penelitian Tanah dan Agroklimat, Bogor. Hal: 26 65.

Suwahyono, U. 2011. Petunjuk Praktis Penggunaan Pupuk Organik Secara Efektif Dan Efisien. Penebar Swadaya, Jakarta.

Syukron, F. 2018. Pembuatan pupuk organik bokashi dari tepung ikan limbah perikanan Waduk Cirata. Sungkai Jurnal Penelitian Pertanian 6:(1) 1-16.

Tan, K. 1991. Dasar-dasar Kimia Tanah. Gadjah Mada University Press. Yogyakarta.

Tuherkih, E dan I.A Sipahutar. 2009. Pengaruh pupuk NPK majemuk (16:16:15) terhadap pertumbuhan dan hasil jagung (Zea Mays L) di tanah Inceptisols. Dalam Anda, M (Ed.). Prosiding Seminar Nasional Dialog Sumberdaya Lahan Pertanian. Balai Besar Penelitian dan Pengembangan Sumberdaya Lahan Pertanian. Penelitian Tanah. Bogor, 18 - 20 November 2008. Hal: 77 - 91.

White R.E. 2006. Introduction to the Principles and Practices of Soil Science. Bllackwell Scientific Publ., Palo Alto, CA. 